\title{
57- Gürcistan'da iki dilli öğrencilerin Türkçeyi öğrenme durumlarına ilişkin öğretmen görüşleri
}

\section{Memet ABUKAN}

APA: Abukan, M. (2021). Gürcistan'da iki dilli öğrencilerin Türkçeyi öğrenme durumlarına ilişkin öğretmen görüşleri. RumeliDE Dil ve Edebiyat Araştırmaları Dergisi, (25), 968-986. DOI: 10.29000/rumelide.1032550.

\section{$\ddot{O} \mathbf{z}$}

Türkiye tarafından yurt dışında yaşayan Türklerin eğitim-öğretim faaliyetlerinin sürdürülebilmesi, dil ve kültüre yönelik taleplerinin karşılanabilmesi gibi pek çok hususta okullar, kurs merkezleri, enstitüler kurulmaktadır. Bu faaliyetlerle onların Türkiye’ye olan güçlü bağlarını devam ettirebilmeleri, kendi dil, kültür, değer ve benliklerini yitirmemeleri ve toplumlar arası köprü kurabilmelerine olanak sağlanmıştır. Gürcistan'ın Batum şehrinde faaliyet gösteren MEB Batum Çok Programlı Anadolu Lisesi de bu amaca yönelik olarak inşa edilmiş ve çok sayıda öğrencinin buradan faydalanmasına imkan sağlanmıştır. Fakat Türkiye'deki öğrencilerden farklı olarak bu gibi okul ya da merkezlerde eğitim gören öğrencilerin öğrenmelerini, algılarını veya yaşamlarını etkileyen pek çok faktörün olduğu bilinmektedir. Bunlardan biri de iki dilli olma durumudur. Öğrencilerin iki veya daha fazla dili bilmesi, öğrenmesi ya da kullanmasıyla ortaya çıkan sorunlar onların öğrenmelerini oldukça etkileyebilmektedir. Yapılan bu çalışmada da belirtilen okulda öğrenim gören kırk sekiz öğrencinin iki dilli olduğu tespit edilmiş ve bu öğrencilerin öğrenmelerini etkileyen sorunları ele alıp bunlara çeşitli çözüm önerileri geliştirebilmek adına öğretmenlerin görüşlerine başvurulmuştur. Bunun için de bir görüşme formu hazırlanmış ve gerekli izinler alındıktan sonra 2020-2021 bahar döneminde öğretmenlere uygulanmış ve elde edilen veriler de nitel araştırma yöntemlerinden biri olan doküman taramasına göre incelenmiştir. Bunun sonucunda iki dilli öğrencilerin öğrenim durumlarında karşılaşılan olumsuzluklardan onları geliştirebilecek önerilere varıncaya kadar birçok bulguya ulaşılmış ve bunlar çeşitli araştırmalarla desteklenerek yorumlanmıştır. Böylece Gürcistan'da iki dilli öğrencilere, öğretmenlere, ebeveynlere yönelik kuramsal ve teorik uygulamalı çalışmalar için neler yapılabileceği konusunda çeşitli öneriler geliştirilmesi amaçlanmıştır. Bu kapsamda çalışma konusu ile alan yazına katkı sağlanmaya çalışılmıştır.

Anahtar kelimeler: Gürcistan'da iki dillilik, Gürcistan'da Türkçe öğretimi, öğretmen görüşleri

\section{Teachers' views on Turkish language learning status of bilingual students in Georgia}

\begin{abstract}
Schools, course centers and institutes are established by Turkey in many aspects such as maintaining the education and training activities of the Turks living abroad and meeting their language and culture demands. With these activities, it is possible for them to maintain their strong ties to Turkey, not to lose their identity, language, culture and values, and to build bridges between societies. As a matter of fact, MEB Batumi Multi-Program Anatolian High School operating in the city of Batumi in Georgia was built for this purpose and many students were able to benefit from it. However, unlike
\end{abstract}

Dr. Öğr. Üyesi, Muş Alparslan Üniversitesi, Sosyal Bilimler Meslek Yüksekokulu, Sivil Havacıllk Kabin Hizmetleri Bölümü (Muş, Türkiye), m.abukan@alparslan.edu.tr, ORCID ID: 00oo-0003-3461-0539 [Araştırma makalesi, Makale kayıt tarihi: 03.11.2021-kabul tarihi: 20.12.2021; DOI: 10.29000/rumelide.1032550] 


\begin{abstract}
the students in Turkey, it can be seen that there are many factors that affect the learning, perceptions and lives of students studying at such schools or centers. One of them is the situation of being bilingual. Problems that arise when students know, learn or use two or more languages can greatly affect their learning. In this study, it was determined that forty eight students studying in the mentioned school were bilingual, and the opinions of the teachers were sought in order to address the problems that affect the learning of these students and to develop various solution suggestions. For this, an interview form was prepared and applied to the teachers in the spring term of 2020-2021 after the necessary permissions were obtained, and the data obtained were examined according to document analysis, which is one of the qualitative research methods. As a result, many findings, ranging from the negativities encountered in the learning situations of bilingual students to suggestions that can improve them, have been reached and these have been interpreted with the support of various researches. Thus, it has been tried to contribute to the literature by developing various suggestions about what can be done for bilingual students in Georgia, both for teachers, parents and institutionally, for theoretical or practical studies.
\end{abstract}

Keywords: Bilingualism in Georgia, Turkish teaching in Georgia, Teachers' views

\title{
1. Giriş
}

Türkiye dünya genelinde eğitim diplomasisi çerçevesinde yürüttüğü çalışmalar ile yurt dışında bulunan vatandaşlarının dil ve kültür faaliyetlerinin gelişimine yönelik ihtiyaçlarını karşılamaktadır. Bununla birlikte Türkiye için eğitim diplomasisi; ekonomik, siyasi vb. alanlarda ülkenin gelişmesine katkıda bulunacak, stratejik anlamda yakın ve uzak hedeflerin gerçekleşmesine destek olacak bir araç olarak görülmektedir. Bu diplomasinin en önemli ayağını Türkçe öğretimi oluşturmaktadır. Gerek yurt dışında yaşayan vatandaşların eğitim-öğretim faaliyetlerini kendi dillerinde sürdürmelerini sağlamak gerekse yabancılara Türkçe öğretimiyle hedef dilin dünya dili olmasına katkı sunmak bu faaliyetin temel iki amacı olarak görülebilir. Fakat buna yönelik çabaların ülke imajından, kültürler arası köprüler inşa etmeye, uluslararası arenada etkinlik kazanmaktan ekonomik, politik vb. kapsamı genişletmeye varıncaya kadar ülkeye çok boyutlu katkılar sağlayacağı da açıktır. Bu hedefler çerçevesinde Türkçenin öğretimine dair yapılacakların ne kadar önemli olduğu görülmekte ve niteliğin artırılmasına yönelik gerek kurumsal gerekse bireysel çalışmalarla bunun daha da ileriye taşınabilmesi gerekmektedir. Hazırlanan bu çalışma da Türkçe öğretiminin daha nitelikli hâle getirilmesi amacını taşımakta ve yurt dışında yaşayan Türk vatandaşlarının öğrenmelerine olumsuz anlamda etki eden hususları tespit edip çözüm önerileri geliştirme amacına yöneliktir. Bu çerçevede Gürcistan'ın Batum şehrinde MEB Batum Çok Programlı Anadolu Lisesinde eğitim gören ve iki dilli olan öğrencilerin öğrenme güçlükleri başta olmak üzere onların öğrenmelerini olumsuz etkileyen hususların çözümüyle Türkçe öğretimine katkı sunmak amaçlanmıştır. MEB Batum Çok Programlı Anadolu Lisesi ya da diğer adıyla Batum Türk Okulu 2016 yılında açılmış ve okul öncesi de dâhil olmak üzere ilk ve orta derecelerde 24 derslikle Batum'daki Türk vatandaşlarının eğitim öğretim faaliyetleri için hizmet vermektedir. Yaklaşık olarak ylllık 250 ile 300 arasında değişen sayıda öğrenci bulunan okulda eğitim öğretim faaliyetleri Türkçe yürütülmektedir. Fakat yabancı dil olarak İngilizcenin dışında Rusça ve Gürcüce dersleri de verilmektedir (Abukan, 2021: 77). Yapılan araştırmalar sonucunda Gürcüce ve Rusça başta olmak üzere farklı dilleri bilen ya da anne ve babasından en az birinin farklı bir dili bilmesinden dolayı buna maruz kalan 48 öğrenci tespit edilmiştir. Bu öğrencilere ve ebeveynlere yönelik herhangi bir çalışma yapılmadan önce ilgili okulda ders veren öğretmenlerin iki veya çok dilli öğrencilerin durumlarına ilişkin görüşlerinin alınmasının daha faydalı olunacağı kanaatine varılmıştır. Dolayısıyla öğretmenlerden elde edilecek bilgilerin öğrencilere yönelik yaş, dil, edinim sırası gibi birçok hususta neler yapılabileceği konusunda ön bir değerlendirme 
niteliği taşıdığı da söylenebilir. Bu açıklamalar çerçevesinde öncelikle “iki dillilik nedir, çok dillilik nedir, iki dilliliğin boyutları nelerdir?” gibi soruların açıklı̆̆a kazandırılması gerekmektedir.

İki dillilik "iki dilli olma durumu, iki dilli ise sıfat görevinde "iki ayrı dili okuyup yazma gücünde ve becerisinde olma” veya “iki ayrı dile sahip olan” biçiminde Güncel Türkçe Sözlük’te (2021) tanımlanmaktadır. Birçok araştırmacının da iki dilliliği genel olarak ana dilin dışında farklı bir dilin de bilinmesi veya kullanılması olarak tanımladıkları görülmektedir (Aksan, 1998: 26; Andrade, 2018: 1; Bican, 2014: 318; Bloomfield, 1935: 56; Güzel, 2010: 30-31; İmer vd., 2011: 153; Vardar, 2002: 118). Fakat yine araştırmalar göstermiştir ki iki dillilik oldukça karmaşık ve çok boyutlu ele alınan bir konudur. Çünkü buna ilişkin yapılacak bir belirlemenin nedenlerine bakıldığında bu durum daha net anlaşılabilir. Örneğin Altıparmak Yılmaz (2020: 31) çalışmasında iki dilliğin oluşumunda "ebeveynlerini ana dillerinin farklı olması, ülke nüfusunun farklı etnik gruplardan oluşması, uzun süre farklı ülkelerde yaşama ve yaşanılan ülkede birden fazla dil olması" şeklinde dört neden sıralar. Dolayısıyla ebeveyn faktöründen etnik yapıya, göçten kültüre kadar birçok alanı ilgilendiren bir konuda net bir tanımlama yapmak oldukça zor olacaktır. Nitekim Hamers ve Blanc (2000), Bloomfield (1935), Baker (2011) gibi birçok araştırmacının yapmış oldukları tanımlamalar da vardır. Fakat bunların iki dilliğin herhangi bir türünü veya boyutunu ön plana çıkaran tespitler olduğu söylenebilir. Bu bağlamda "ana dilin dışında farklı bir dilin de bilinmesi veya kullanılması” biçiminde yapılan tanımlamanın bir ölçüt olarak iki dillilik üzerine yapılacak araştırmalarda yeterli olabileceği düşünülse de bunu iki dilliliğin boyutları için belirtmek oldukça zordur. Bu çerçevede öğrenciler üzerinde yapılabilecek araştırmalarda iki dilliliğin oluşum nedenleri dikkate alınarak iki dilliliğin boyutları üzerinde durmak gerekecektir. Bu konuda Wang (2021: 17) tarafından yapılan bir çalışmada edinme yaşı, edinme bağlamı, edinmenin sonucu ve sırası, bilişsel organizasyon, (göreceli) yetkinlik/yeterlilik, işlevsel yetenek, dışsallık, kültürel kimlik, dillerin sosyal kültürel durumu başlıkları altında eklemeli iki dillilikten pasif iki dilliliğe, ergen iki dillikten kültürel iki dilliğe varıncaya kadar iki dilliliğin incelenmesinde gerekli pek çok boyut belirlenmiştir. Dolayısıyla başta öğrenci ve ebeveynler olmak üzere iki dillilikle ilgili yapılacak çalışmalarda iki dilliliğin boyutuna göre bir belirleme yapmak gerekecektir.

Yapılan çalışmada iki dillilikle beraber çok dilliliğe de değinmekte fayda vardır. APA Psikoloji Sözlüğü’ne (2021) göre çok dillilik, "genellikle coğrafi, ekonomik, politik veya militarist etkileşimlerden kaynaklanan; aynı topluluk içinde birkaç dilin kullanıldığı sosyo-dilsel durum" olarak tanımlanmıştır. Benzer şekilde çok dilliliğin, bir birey ya da topluluğun iki veya daha fazla dili kullanma durumu olarak ele alındığı çalışmalar da görülmektedir (Jasone and Genesee, 1998; Tucker, 1999). Avrupa Birliği Konseyi (2005: 3) de "Çok dillilik, hem bir kişinin birkaç dili kullanma yeteneğini hem de farklı dil topluluklarının bir coğrafi alanda bir arada yaşamasını ifade eder." şeklinde bir tanım yapar. Bu çerçevede çok dilliliğin iki dilliliğe oranla sayı olarak daha kapsayıcı bir kavrama karşılık geldiği anlaşılmaktadır. Çakır da (2016: 79) çalışmasında farklı toplumların bir arada yaşamanın getirmiş olduğu bir sonuç olarak çok dilliliği görür ve gelişen şartlar çerçevesinde çocukların iki dilli olabileceğini hatta üç ya da dört farklı dili konuşabilen bireylerin de olabileceğini belirtir. Bu durumu da çok dillilik olarak niteler. Gerek iki dilliliğe gerekse çok dilliliğe ilişkin araştırmacılar tarafından yapılan bu tespitlerle konunun anlaşılmasına çalışılmıştır. Dolayısıyla yapılan çalışmada çok dilliliği de içeren iki dilliliğe atıfla konu ele alınmıştır. Bu nedenle araştırmada iki dilli ve çok dilli şeklinde bir ayrıma gidilmemiştir. Fakat öğrencilere yönelik yapılacak çalışmalarda iki dilli olmayla çok dilli olma arasındaki farka yönelik bulguların ya da araştırmaların önemli olduğu düşünülmektedir. 


\subsection{Araştırmanın amacı}

Araştırmanın genel amacı, Gürcistan'da iki dilli öğrencilerin Türkçeyi öğrenme ve kullanabilme becerilerine dair olumlu ve olumsuz hususları öğretmenlerin görüşlerine göre tespit etmektir. Bu amaca yönelik olarak çalışmada öğretmenlere on dokuz soru yöneltilmiştir. Bu soruların altısı öğretmenlerin hangi ülke vatandaşı olduğu, kaç yıl öğretmenlik yaptığı, yaş, cinsiyet, doğum yeri ve anadilinin ne olduğu şeklinde kişisel bilgilere yönelik; diğer on üç soru ise iki dilli öğrencilere yöneliktir. Dolayısıyla toplamda on dokuz sorudan oluşan bu çalışmada genel amaç ve bütünlük dikkate alınarak aşağıdaki sorulara yanıt aranmıştır.

1. Gürcistan'da iki dilli öğrencilerle ilgili karşılaştığınız olumsuzluklar nelerdir? (İki dilliliğin başarıyamotivasyona vb. etkisi açısından)

2. Gürcistan'da iki dilli öğrencilerle ilgili karşılaştığınız olumlu hususlar nelerdir? (İki dilliliğin başarıyamotivasyona vb. etkisi açısından)

3. Gürcistan'da iki dilli öğrenciler için Türkçe derslerine ayrılan süre yeterli midir? Yeterli değilse nedenini açıklar mısınız?

4. Gürcistan'da iki dilli öğrencilere yönelik Türkçe ek ders yapılmasına ihtiyaç var mıdır? İhtiyaç varsa bunun nedenleri nelerdir?

5. Gürcistan’da iki dilli öğrencilerde karşllaşllan olumsuzluklara yönelik ne tür çözümler önerirsiniz?

6. Gürcistan'da iki dilli olmayan öğrencilerin Türkçeyi doğru kullanamadıklarını düşünüyorsanız bu durumu hangi nedenlere bağlayabilirsiniz?

7. Gürcistan'da iki dilli öğrencilerin Türkçeyi doğru kullanma becerilerine yönelik gözlemlediğiniz en önemli problemler nelerdir?

8. Gürcistan'daki öğrencilerin iki veya daha fazla dili (Türkçe, Gürcüce, Rusça, İngilizce vb.) karışık olarak kullandıkları durumlar oluyor mu? Neden?

9. Gürcistan'da iki dilli öğrencilerin daha çok hangi dil becerilerine (konuşma - dinleme - yazma okuma) yönelik çalışma yapılması gerektiğini düşünüyorsunuz? Neden?

10. Gürcistan'da iki dilli öğrencilerin en çok hangi beceriyi kullanmakta zorlandıklarını gözlemliyorsunuz? Nedeni ne olabilir?

11. Gürcistan'da iki dilli öğrencilerin en çok hangi beceride başarılı olduklarını gözlemliyorsunuz? Nedenini açıklar mısınız?

12. Gürcistan'da Türkçe öğretimi ve öğrenimi adına yaşanan eksiklikler/sorunlar nelerdir?

13. Türkçe'nin ve Türk kültürünün Gürcü kültürü ile etkileşimi çerçevesinde daha verimli aktarımını sağlamak için önerileriniz nelerdir? 


\section{Yöntem}

\section{1. Araștırmanın deseni}

Gürcistan'da iki dilli öğrencilerin Türkçeyi öğrenme durumlarını öğretmen görüşlerine göre ortaya koymaya yönelik olarak yapılan bu çalışmada nitel araştırma yöntemlerinden biri olan doküman incelemesinden yararlanılmıştır. Bu teknik, "araştııılması hedeflenen olgu veya olgular hakkında bilgi içeren yazılı materyallerin analizini kapsar”. Buna göre var olan ya da çeşitli araştırma sorularıyla elde edilen yazılı materyaller belirlenmiş kurallara göre araştırmacı tarafından derinlemesine incelenir ve veriler çözümlenmeye çalışılır. Böylece tespit edilen bulgularla yapılan çalışmanın bilimsel genellemesi kuramsal önermelerle yapılmış olur. Bu tekniğe göre çalışmanın başından sonuna kadar araştırmacının izlemesi gereken birtakım aşamalar söz konusudur. Bunlar; "dokümanlara ulaşma, özgünlüğü kontrol etme, dokümanları anlama, veriyi analiz etme ve veriyi kullanma"dır. Dolayısıyla yapılacak çalışmada araştırmacının elde ettiği/edeceği verilerle bilimsel bir genellemeye ulaşabilmesi için bu yöntemin belirlediği aşamalara göre araştırmanın yürütülmesi gerekmektedir (Ylldırım ve Şimşek, 2011).

\section{2. Araştırma grubu}

Çalışmanın bulgularına ulaşabilme adına araştırmacı tarafından hazırlanan yarı yapılandırılmış görüşme formuna sekiz öğretmen katılmıştır. Katılımcıların tamamının 40 ve 45 yaş aralığında ve 18 ile 23 yl arasında değişen öğretmenlik deneyimine sahip oldukları; ana dillerinin Türkçe, doğum yerleriyle uyruklarının da Türkiye olduğu belirlenmiştir. Ayrıca öğretmenlerden sadece birinin kadın, geriye kalanların ise erkek olduğu belirlenmiştir. Çalışmada katılımcı sayının az olması çalışmanın niteliği konusunda tereddüt oluşturmamalıdır. Çünkü ayrıntılı bir değerlendirme yapabilmede çalışma grubunun sınırlılığı araştırmanın bütününü verebilecek şekilde genellenecek bilgileri sağlayabilir. Elde edilen veriler ve bulgulara bakıldığında da bu sayının yeterli olduğu söylenebilir.

\section{3. Verilerin toplanması}

Gürcistan'da iki dilli öğrencilerin Türkçeyi öğrenme durumlarını öğretmen görüşlerine göre tespit edebilmek amacıyla ilkin MEB Batum Çok Programlı Anadolu Lisesinde öğrenim gören iki dilli öğrencilerin sayısı belirlenmiş̧tir. Okul idarecilerinden elde edilen verilere göre 48 öğrencinin iki dilli olduğu saptanmıştır. Araştırma sürecinde çalışma grubunun belirlenmesi, araştırmaların en önemli faktörlerinden birisi olduğu için bu öğrencilerin sorunlarının öğretmenler tarafından tespitinin ilk aşamada yapılmasının daha faydalı olabileceği öngörülmüştür. Bunun için de ilgili okulda derse göre öğretmenlere yönelik bir çalışma yapılması kararlaştırılmıştır. Böylece elde edilecek bulgulardan iki dilli öğrencilere yönelik ne tür sorunların olduğu ve ne gibi çalışmalar yapılacağı konusunda bir düşünceye ulaşmak mümkün olacaktır. Bunun için de Altıparmak Yılmaz (2020) tarafından iki dilli öğrencilerin öğretmenlerine yönelik olarak hazırlanmış ve uygulanmış olan bir görüşme formundan yararlanılmıştır. Araştırmacı tarafından 19 sorudan oluşan bir form hazırlanmış ve formdaki maddelerle ilgili olarak ülkeye ve hedef kitleye yönelik bazı ufak değişiklikleri yapabilmek ve formu kullanabilmek için gerekli etik izinler alınmıştır. Daha sonra alan uzmanı iki akademisyenin görüşlerine de başvurarak çalışmanın formuna son hâli verilmiştir. Ayrıca araştımanın uygulanabilmesi için Tiflis Eğitim Müşavirliğinden de gerekli izinler alınmıştır. Nitekim yapılan çalışma MEB Avrupa Birliği ve Dış İlişkiler Genel Müdürlüğü tarafından düzenlenen Burada Türkçe Konuşuyor Projesi kapsamında hazırlanmıştır. Daha sonra Gürcistan'da İki Dillilik - Öğretmen Görüşme Formu adlı veri toplama aracının okulda görev yapan öğretmenlere uygulama aşamasına geçilmiştir. Konunun önemi ve çalışmanın nesnelliği açısından her 
bir öğretmenin tespitinin ne denli gerekli olduğu hususunda öğretmenler bilgilendirilmiştir. Özellikle okul öncesi, sınıf öğretmeni, Türkçe öğretmeni, İngilizce öğretmeni gibi dallarda görev yapan öğretmenlerin iki dilli öğrencilerin dil becerisi ve gelişimine yönelik ayrıntılı açıklamalar yapmasının önemi üzerinde durulmuştur. Daha sonra internet üzerinden formlar öğretmenlere gönderilmiş ve böylece verilerin toplanması sağlanmıştır.

\section{4. Verilerin analizi}

Verilerin değerlendirilmesinde doküman incelemesinden yararlanılmıştır. Bu tekniğin aşamalarından biri olan "veriyi analiz etme"de dokümanlar "analize konu olan veriden örneklem seçme, kategorilerin seçilmesi, analiz biriminin saptanması ve sayısallaştırma" başlıkları altında değerlendirilir (Yıldırım ve Şimşek, 2011). Yapılan çalışmada da bu aşamalara dikkat edilerek araştırmanın analizi, kategorilerin geliştirilmesinden sayısal verilere kadar birçok hususta yapılmıştır. Nitekim çalışma grubundakilerin her birine farklı numaralar verilmek suretiyle veriler sınıflandırılmış ve bunlar ayrı ayrı isimler hâlinde oluşturularak araştırmanın bütünlüğü sağlanmaya çalışılmıştır. Verilerin mantıksal bir sıra izlenerek oluşturulması onların kodlanmasını da kolaylaştırmıştır. Çünkü öğretmenlerden elde edilen her bir veri konunun içeriğine ilişkin kodlamalarla gruplandırılmış ve değerlendirilmiştir. Böylece Gürcistan'da iki dilli öğrencilerin Türkçeyi öğrenme durumlarına dair öğretmen görüşleriyle ilgili bulgular tespit edilmiştir.

\section{Bulgular}

Çalışmada iki dillilere ilişkin elde edilen bulgular tablolar hâlinde aşağıda gösterilmiştir. Ayrıca tablolarda bazı katılımcıların ifadeleri birden fazla kod altına yerleştirildiği için frekans ve yüzdeleri katılımcı sayısını aşabilir.

3. 1. İki dilli öğrencilerde karşılaşılan olumsuzluklara yönelik öğretmen görüşlerine ilişkin bulgular

Tablo 1: İki dilli öğrencilerde görülen olumsuzlukların çözümüne ilişkin kod, frekans ve yüzdeler.

\begin{tabular}{llll}
\hline Kod No & Kodlar & $\mathrm{f}$ & $\%$ \\
\hline 1 & İlköğretime başlarken Türkçenin hiç bilinmemesi & 2 & 25 \\
2 & Ebeveynlerden birinin hiç Türkçe bilmemesi & 1 & 12,5 \\
3 & Kendini ifade edememe & 1 & 12,5 \\
4 & Derse katılım sağlamama & 1 & 12,5 \\
5 & Mecaz, yan anlam vb. üst dil becerilerini anlayamama & 2 & 25 \\
6 & Kavramları anlayamama & 2 & 25 \\
7 & Sözcük dağarcı̆̆ının yetersizliği & 1 & 12,5 \\
8 & Öğrenme güçlüğü & 1 & 12,5 \\
\hline
\end{tabular}

Tablo 1 incelendiğinde iki dilli öğrencilerde karşılaşılan olumsuzluklara ilişkin toplam 8 kodlama yapılmıştır. Bu kodlamaların içeriğine bakıldığında öğrencilerin okula başladığında hiç Türkçe bilmemesinden üst dil becerilerini anlayamamaya kadar farklı ama birbirine yakın görüşler tespit edilmiştir. Bu bulgular her ne kadar öğrencinin başlangıçta Türkçe bilmemesinden kaynaklı sorunlar 
olarak görülse de sonraki aşamalarda derse katılım sağlayamamaya varıncaya dek özgüven eksikliği vb. birçok psikolojik sorunlara evrilebilecek bir durum da arz edebilir. Bu çerçevede öğrenciler üzerinde düzey ve boyut dikkate alınarak çalışmalar yapılması gerekmektedir. Bulguların içeriğine ya da kodlarına ilişkin öğretmenlere ait bazı görüşler ise şöyledir:

Ö1: "Özellikle ilkokula başlarken Türkçe bilinmemesi, anne ya da babadan herhangi birinin Türkçe bilmemesi öğrencinin dil sorunu yaşamayan akranlarından geri kalmasına neden olmaktadır."

Ö2: "Kendini ifade edebilmede bazen çok büyük problem yaşadıklarında pes edenler olabiliyor, yanlş yaparım ya da hatah bir cümle kurarm diye... Öğrenci pasif olarak sadece ders dinlemekle yetiniyor, derse katılim göstermeyince bu da motivasyonunu, başarısım olumsuz etkiliyor...”

Ö4: "Türkçeye ait mecaz ve yan anlam içeren kullanımları anlamakta zorluk çekebiliyorlar."

Ö5: "En büyük olumsuzluk, Türkçeye tam manasıyla hâkim olmayan öğrencilerimizin kavramları algılamada karşılaştıkları problemlerdir. Türkçeye hâkim olduktan sonra genel olarak sinıfin en başarılı öğrencileri."

Ö6: "Özellikle birinci sınıfa başlarken öğrencinin Türkçeyi kullanma becerisinin akranlarından daha düsük olması nedeniyle okuma ve yazma öğrenme güçlüğü, kelime hazinesinin yetersiz olması nedeniyle söylenenleri tam anlamama ve kavramlarla eşleştirememe gibi sorunlar yaşanmaktadir."

Ö8: "Olumsuz bir etki görmedim fakat çok nadiren olsa da bir dilde bir kelimenin başka anlamlarmı bilmemesi ögrencide olumsuz etki edebilir."

3. 2. Başarı ve motivasyon açısından iki dilli öğrencilerde karşılaşılan olumlu hususlara yönelik öğretmen görüşlerine ilişkin bulgular

Tablo 2: Öğretmenlerin iki dilli öğrencilerde karşılaştıkları olumluluğa ilişkin kod, frekans ve yüzdeler.

\begin{tabular}{llll}
\hline Kod No & Kodlar & $\mathrm{f}$ & $\%$ \\
\hline 1 & Farklı dilleri kolayca öğrenebilme & 2 & 25 \\
2 & Karşılaştırma yapabilme & 1 & 12,5 \\
3 & Güçlü iletişim becerisine sahip olma & 2 & 25 \\
4 & Çok yönlü olabilme & 1 & 12,5 \\
5 & Kültürler arası etkileşimi sağlama & 2 & 25 \\
\hline
\end{tabular}

Öğretmenlere göre iki dilli öğrencilerde karşılaşılan olumlu yönler onların farklı dilleri kolayca öğrenebilmelerinden güçlü iletişim becerilerine kadar farklılık gösterebilmektedir. Bunlara ilişkin elde edilen görüşlerden bazıları şöyledir:

Ö1: "Türkçeyi öğrendikten sonra diğer dilleri çok kolay öğrenmektedirler."

Ö2: "Çoğulculuk her zaman için zenginliktir... Kültürler arası etkileşim toplumların gelişiminde olumlu etkiye sahiptir."

Ö4: "iki dil arasında kıyas yaparak kahıı olarak daha kolay öğrendiklerini düşünüyorum.”

Ö5: "Çocuklar daha girişken, iletişim becerileri kuvvetli."

Ö6: "Ailenin de desteği olursa arkadaşlarıyla rahat iletişim kurmak adına hızh bir öğrenme periyodu geçirmekteler. İlerleyen sinfflarda diğer dillerin öğrenilmesi iki dilli öğrenciler için daha kolay olmakta ve bu durumda onları motive etmektedir."

Ö7: “Çok yönlü oluyorlar."

Ö8: "Öğrencilerin diller arasında karşllaştırma yaparak kendilerini ifade etme çabası diğer öğrencilerle sosyal etkileşimi arttırması." 
3. 3. İki dilli öğrenciler için Türkçe derslerine ayrılan sürenin yeterliliğine dair öğretmen görüşlerine ilişkin bulgular

Tablo 3: İki dilli öğrenciler için Türkçe ders süresinin yeterliliğine ilişkin kod, frekans ve yüzdeler.

\begin{tabular}{llll}
\hline Kod No & Kodlar & $\mathrm{f}$ & $\%$ \\
\hline 1 & Ders saatleri yeterli & 6 & 75 \\
2 & Ders saati arttırlmall & 2 & 25 \\
\hline
\end{tabular}

Öğretmenlerin çoğunluğu Türkçe derslerinin yeterli olduğu konusunda görüş bildirmişlerdir. İki öğretmen ise iki dilli öğrenciler için ders saatlerinin yeterli olmadığını belirtmişlerdir. Dolayısıyla hangi sınıf, düzey ve boyuta göre bunun belirtildiğine yönelik öğrenciler özelinde bir araştırmaya ihtiyaç duyulmaktadır. Öğretmenlerin ders sürelerinin yeterliliğine ilişkin bazı görüşleri ise şöyledir:

Ö1-3: "Evet."

Ö2: "Okulumuzda öğrenim olarak her kademede Türkçe ders saati yeterli şekilde programa konulmuştur."

Ö4: "Yetersiz çünkü okul dışında pratik yapabilecekleri ortam yok."

Ö5: "Hiç Türkçe bilmeden okula gelen öğrenciler için sürenin yetersiz olduğunu düşünüyorum. Sürekli geriden gelen bir öğrenci profili çizmektedirler.”

3. 4. İki dilli öğrenciler için Türkçe öğrenimi açısından ek derslerin yapılıp/yapılmamasına dair öğretmen görüşlerine ilişkin bulgular

Tablo 4: İki dilli öğrenciler için ek derslere ilişkin kod, frekans ve yüzdeler.

\begin{tabular}{llll}
\hline Kod No & Kodlar & $\mathrm{f}$ & $\%$ \\
\hline 1 & Ek dersler yapılmalı & 4 & 50 \\
2 & Ek derslere ihtiyaç yok & 3 & 37,5 \\
3 & Bireysel çalışmalı & 1 & 12,5 \\
\hline
\end{tabular}

Tablo 4’te öğretmenlerin yarısının iki dilli öğrenciler için ek ders yapılmasının gerekliliğini saptadıkları görülmektedir. Bu tespit iki dilli öğrenciler için çalışmalar yapılması konusunda bir fikir verebilmektedir. Bunun yanında gerekli olmadığını ya da bireysel çalışmaların yeterli olacağını ifade eden öğretmenler de olmuştur. Kodlara ilişkin katılımcılardan bazılarının görüşleri ise şöyledir:

Ö2: "Ĕ̆er ilk kademelerde Türkçe ve diğer yabancı dillerin öğrenilmesi hedefleniyorsa haftalkk ders saatlerinde bir veya iki ders saati artturlabilir... Öğrenilmesi istenilen ve zayıf oldukları dillerde tiyatro ya da münazara gibi kendilerini ifade edebilecekleri sosyal etkinliklere ağırlı verilmeli."

Ö5: “Gerekli, çünkü çocuklartn Türkçe konuşabilecekleri ortam kısıtl.”

ö6: "Hiç Türkçe konuşamayan öğrenciler için takviye bir çahşma yapılması gerektiğini düşünüyorum. Az da olsa Türkçe konuşabilen öğrenci daha hızh ilerlerken hiç bilmeyen öğrenciler için zor bir süreç yaşanmaktadır."

Ö7: "Ders dışında bireysel çalışmaları gerekir."

Ö1- 4-8: "Hayrr." 
3. 5. İki dilli öğrencilerde yaşanan olumsuzlukların çözümüne yönelik öğretmen görüşlerine ilişkin bulgular

Tablo 5: İki dilli öğrencilerde görülen olumsuzlukların çözümüne ilişkin kod, frekans ve yüzdeler.

\begin{tabular}{llcc}
\hline Kod No & Kodlar & $\mathrm{f}$ & $\%$ \\
\hline 1 & Okul öncesinde dil çalışmaları yapılmalı & 1 & 12,5 \\
2 & Bolca okuma yapmalı & 2 & 25 \\
3 & Ek dersler yapılmalı & 1 & 12,5 \\
4 & Geziler düzenlenmeli & 1 & 12,5 \\
5 & Ebeveynler için kurslar & 2 & 25 \\
6 & Kreşler açılmalı & 2 & 25 \\
7 & Takviye çalışmalar yapılmalı & 1 & 12,5 \\
8 & Düzeye göre dil becerileri ölçülmeli & 1 & 12,5 \\
9 & Konuşma becerisine yönelik ortamlar sağlanmalı & 1 & 12,5 \\
\hline
\end{tabular}

Öğretmenlere iki dilli öğrencilerin sorunlarına yönelik ne tür çözümler önerebilecekleri de sorulmuş ve onlardan elde edilen bazı yanıtlar şu şekildedir:

Ö1: "Özellikle ana sinıfinda dil konusunda çalş̧malar yapılmahdır.”

Ö3: "Türkçe metinlerden okuma yapma."

Ö5: "Yurt dışında yaşayan yabancı uyruklu vatandaşlarımızın büyük çoğunluğu evde bulunulan ülkedeki dili konuştuğundan evdeki çocuklarmn Türkçeyi öğrenme şansı çok az. Türkçe bilmeyen ebeveynler için kurslar açlmah, çocukların eğitimine katkıda bulunmaları için, çocuklar için kreşler açllmalı. İlkokula başlayan çocuklardan Türkçe bilmeyen öğrenci sayısı oldukça fazla."

Ö6: "Dil gelişimine yönelik süreklilik gerektiren bir çalsşmaya tabi olunmahdır. Zaman zaman yaşlarına göre dil bilme seviyeleri ölçülmeli ve gerekiyorsa takviye çalş̧malar planlanmalıdır."

ö8: "Konuşma pratiği yapacak ortamda bulunmayı.”

3. 6. Gürcistan'da yaşayan ve iki dilli olmayan öğrencilerin Türkçeyi yeterince etkili kullanamama nedenlerine yönelik öğretmen görüşlerine ilişkin bulgular

Tablo 6: İki dilli olmayan öğrencilerin Türkçe kullanımlarına ilişkin kod, frekans ve yüzdeler.

\begin{tabular}{clll}
\hline Kod No & Kodlar & $\mathrm{f}$ & $\%$ \\
\hline 1 & İyi kullanıorlar & 8 & 100 \\
2 & Kimi zaman yöresel kullanımlar & 1 & 12,5 \\
\hline
\end{tabular}

Çalışmada bir karşılaştırma yapabilmek adına iki dilli olmayanlar öğrencilerin Türkçeyi kullanım durumlarına ilişkin de öğretmenlere bir soru yöneltilmiştir. Buna göre kimi zaman yöresel kullanımlar kimi zaman da okula başlangıç düzeyinde yetersizlikler görülse de katılımcıların tamamı iki dilli olmayan öğrencilerin Türkçeyi kullanma konusunda başarılı bulduklarını belirtmiştir. Buna yönelik bazı görüşler şöyledir: 
Ö3: "Türkçeyi iyi kullaniyorlar."

Ö6: "Türkçeyi genel olarak iyi kullaniyorlar."

Ö7: "Başlangıçtaki sorun maksimum 2 yıl içerisinde çözülmektedir."

Ö8: “...Türk bile olsa onlarmda geleneksel halk ağziyla konuşmaları çocukların tek yönlü olarak okuldan destek alarak Türkçeyi öğrenmelerine neden oluyor.”

3. 7. Gürcistan'daki öğrencilerin Türkçeyi kullanabilme becerilerindeki problemlere dair öğretmen görüşlerine ilişkin bulgular

Tablo 7: Öğretmenlerin dil becerilerinde karşılaştıkları sorunlara ilişkin kod, frekans ve yüzdeler.

\begin{tabular}{llcc}
\hline Kod No & Kodlar & $\mathrm{f}$ & $\%$ \\
\hline 1 & Ebeveynlerin ilgisizliği & 1 & 12,5 \\
2 & Aile ortamında Türkçenin etkin kullanılmaması & 1 & 12,5 \\
3 & Sözcük dağarcı̆̆ındaki yetersizlik & 1 & 12,5 \\
4 & Teknolojinin etkisi & 1 & 12,5 \\
5 & Kavramların algılanmayışı & 1 & 12,5 \\
6 & Kavramları anlayamama & 1 & 12,5 \\
7 & Sosyal becerilerinin zayıflı̆̆ & 1 & 12,5 \\
8 & Olumsuz aktarımlar yapma & 1 & 12,5 \\
\hline
\end{tabular}

Öğretmenler iki dilli öğrencilerin karşılaştıkları sorunlara ilişkin farklı görüşler ileri sürmüşlerdir. Buna yönelik öğretmen görüşlerinden bazıları şöyledir:

Ö1: "Ailelerinin dil kullanmminda yeteri kadar ilgili olamamalar.."

Ö2: "Düzgün Türkçe konuşulmaması sadece okulda verilen akademik destekle olmaz, bunun yanında aile ortamında kullanılan dil ağırlkta, anneler Gürcü, çocuk yeni öğrendiği kelimeleri okulun dışındaki sosyal hayatında da kullanmalı... Bu olumsuz durumlara neden olabiliyor."

Ö4: "Teknolojinin etkisi altında kalma, dilin inceliklerine sahip olmama."

Ö5: “Öğrencilerin kavramları algılayamayışı, kelime hazinelerinin ülkemizde yaşayan öğrencilere oranla daha dar olması. Evde Türkçenin konuşulmaması... Çocuklarının daha iyi Türkçe öğrenmelerini isteyen ebeveynlerin de bu ortama sahip olmamasl."

Ö6: "Özellikle ilkokulun ilk yıllarında smıf arkadaşlarıyla yeterli iletissim kuramamasindan dolayı sosyal yönlerinin zayıf olmaları ve sürekli kendi dillerini bilen arkadaş edinme istekleri. Özellikle annelerin Gürcü olması ve çocukların ana dili olarak Gürcüce öğrenmeleri, babalarn dil gelişimine gereken önemi vermemeleri ve annelerin yeterli oranda Türkçe bilmemeleri başlica nedenlerdir."

ö8: "Argo, olumsuz veya karşı düşüncelerini kendi dilinde arkadaşlarna ifade etme durumu."

3. 8. Gürcistan'daki öğrencilerin iki dili (Türkçe, Gürcüce, Rusça, İngilizce vb.) karışı olarak kullandıkları durumlara yönelik öğretmen görüşlerine ilişkin bulgular 
Tablo 8: Öğrencilerin her iki dili karışık olarak kullanma durumlarına ilişkin kod, frekans ve yüzdeler.

\begin{tabular}{llcc}
\hline Kod No & Kodlar & $\mathrm{f}$ & $\%$ \\
\hline 1 & Baskın dille eksikliklerin tamamlanması & 1 & 12,5 \\
2 & Olumsuz Aktarım (Negatif Transfer) & 1 & 12,5 \\
3 & Konuşulan dillere hâkim olamama & 1 & 12,5 \\
4 & Nadiren & 2 & 25 \\
5 & Olmuyor/Hayır & 4 & 50 \\
\hline
\end{tabular}

Çalışmada öğretmenlere öğrencilerin öğrendikleri dilleri karışık kullanıp kullanmadıkları da sorulmuştur. Buna göre katılımcıların yarısı olumsuz aktarma, iyi bilinen dille eksikliklerin tamamlanması gibi farklı nedenleri sıraladıkları tespit edilmiştir. İki öğretmenin de böyle bir durumla nadiren karşılaştıklarını belirtmişlerdir. Kodlarda belirtilen hususlara ilişkin bazı öğretmen görüşleri ise şu şekildedir:

Ö2: “Evet, karışık kullanıyorlar. Çünkü cümle kurarken eksik bildikleri dili çok iyi bildiği dil ile tamamlamaya çalışması..."

Ö5: "Olabiliyor. Negatif transferden kaynaklanabiliyor. Diğer bir sebep de konuşulan dillere tam olarak hâkim olunamaması olabilir.”

3. 9. İki dilli öğrencilerin dil becerilerine dair çalışmalar yapılmasına yönelik öğretmen görüşlerine ilişkin bulgular

Tablo 9: İki dilli öğrencilerin dil becerilerine dair çalışmaların yapılmasına ilişkin kod, frekans ve yüzdeler.

\begin{tabular}{llll}
\hline Kod No & Kodlar & $\mathrm{f}$ & $\%$ \\
\hline 1 & Tüm beceriler / Türkçe & 5 & 62,5 \\
2 & Konuşma & 1 & 12,5 \\
3 & Konuşma ve dinleme & 1 & 12,5 \\
4 & Konuşma ve okuma & 1 & 12,5 \\
5 & Okuma ve yazma & 1 & 12,5 \\
\hline
\end{tabular}

Öğretmenlerin tüm beceri alanlarını kapsayacak şekilde iki dilli öğrencilere yönelik çalışmalar yapılması gerektiğini ifade ettikleri saptanmıştır. Fakat beceri alanları içerisinde konuşmaya yönelik çalışmaların yapılması gerektiği öne çıkmaktadır. Gerek konuşma gerekse diğer beceri alanlarına yönelik görüşlerden bazıları şöyledir:

Ö4: "Konuşma ve okumanın çok faydah sonuçları olacağı düşüncesindeyim. Okuma öğrencilerin sadece konuşarak öğrenmeyeceğine olanak sağlar. Kelime dağarcığını zenginleştirir. Konuşma da öğrendiği kelimeleri kullanmasina olanak verir."

Ö6: "Daha çok konuşma ve dinleme çalışmaları yapılmalıdır."

3. 10. İki dilli öğrencilerin en çok zorlandıkları dil becerisi ve bunun nedenlerine dair öğretmen görüşlerine ilişkin bulgular 
Tablo 10: Öğrencilerin en çok zorlandıkları dil becerilerine ilişkin kod, frekans ve yüzdeler.

\begin{tabular}{llcc}
\hline Kod No & Kodlar & $\mathrm{f}$ & $\%$ \\
\hline 1 & Konuşma becerisi & 1 & 12,5 \\
2 & "Ü, ş, ç” seslerinin sesletimi & 1 & 12,5 \\
3 & Yazma becerisi & 2 & 25 \\
4 & Dinlediğini anlayamama & 1 & 12,5 \\
5 & Okuma becerisi & 2 & 25 \\
6 & Sözcük dağarcı̆̆ının yetersiz oluşu & 1 & 12,5 \\
7 & Okuduğunu anlayamama & 1 & 12,5 \\
\hline
\end{tabular}

Bir önceki soruyla ilişkili olarak öğretmenlere öğrencilerin en çok zorlandıkları beceri alanı sorulmuş ve onlardan gelen yanıtlar çerçevesinde tüm beceri alanlarına yönelik olumsuzlukların görüldüğü tespit edilmiştir. Buna ilişkin bazı katılımcıların görüşleri şu şekildedir:

Ö1: "Ü, ş, ç gibi harfleri kullanmakta çok zorlaniyorlar."

Ö2: "Yorumlama kabiliyetleri, çıkarımda bulunma ve akıl yürütme yönünden çok zayıflar... Bilgiyi diğer alanda, nerede, nasll uygulayıp tatbik edeceklerini bilmiyorlar... Nedenleri az kitap okuma, kelime haznelerinin daralmasına yol açmakta... Bir diğer neden okuduğunu anlamadiğından ezbere yönelik ders çalışması... Öğrencileri uygulamah çalı̧̧malara yönlendirmek bilginin kahıı olmasını sağlayacaktır."

Ö4: "Okuma. Teknolojik aygitlara olan aşırı ilgi."

Ö6: "Kelime dağarcığının yeterli olmaması nedeniyle konuşma ve anlamada zorlandıklarımı düşünüyorum.”

Ö7: "Okuma ve yazma becerileri düşük, çünkü bu konuda etkinlik yapmiyorlar."

ö8: "Olumsuz duyguları, öfkeleri bazen kendi dillerinde ifade etme."

3. 11. İki dilli öğrencilerin en çok başarılı oldukları dil becerisi ve bunun nedenlerine yönelik öğretmen görüşlerine ilişkin bulgular

Tablo 11: İki dilli öğrencilerin en başarılı oldukları dil becerilerine ilişkin kod, frekans ve yüzdeler.

\begin{tabular}{llcc}
\hline Kod No & Kodlar & $\mathrm{f}$ & $\%$ \\
\hline 1 & Konuşma becerisi & 2 & 25 \\
2 & Okuma becerisi & 1 & 12,5 \\
3 & İletişim & 1 & 12,5 \\
\hline
\end{tabular}

Öğretmenler iki dilli öğrencilerinin konuşma, okuma ve iletişim becerilerinde başarılı olduklarını belirtmişlerdir. Bu tespitlerin hangi sınıf ya da düzeye yönelik olduğunun tespitiyle konunun daha iyi anlaşılacağı düşünülmektedir. Bunun için de öğrencilere yönelik çalışmalar yapılması gerekmektedir. Tablo 11'de belirtilen kodlamalara yönelik bazı öğretmen görüşleri ise şu şekildedir:

Ö5: "Yurt dışında yaşayan öğrencilerimizin uygun ortamı bulduklarında yeni bir dil ediniminde ve iletişim kurmada başarılı olduklarını düşünüyorum."

ö6: “Üçüncü bir dil öğrenirken daha başarth olduklarını düşünüyorum.” 
Ö7: "Konuşma, çünkü özel bir çahş̧maya ihtiyaçları yok."

ö8: "Sosyal etkinlikler de şïr ve kompozisyon okuma, başar hazzı yaşatıyor."

3. 12. Gürcistan'da Türkçe öğretimi ve öğrenimi adına yaşanan eksiklikler/sorunlara yönelik öğretmen görüşlerine ilişkin bulgular

Tablo 12: Gürcistan'da Türkçe eğitimi ve öğretimi adına yaşanan eksiklere/sorunlara ilişkin kod, frekans ve yüzdeler.

\begin{tabular}{lllc}
\hline Kod No & Kodlar & $\mathrm{f}$ & $\%$ \\
\hline 1 & Ortak sosyal, kültürel ve sanatsal etkinlilerin azlığı & 1 & 12,5 \\
2 & Dil konusunda ek çalışmalar yapılması & 1 & 12,5 \\
3 & Kurumsallaşmanın henüz gerçekleşmemesi & 1 & 12,5 \\
4 & Sorun yok & 5 & 62,5 \\
\hline
\end{tabular}

Çalışmada Gürcistan’da Türkçe öğretimi ve öğrenimine yönelik sorunların öğretmenlere göre tespitinin yapılması da amaçlanmıştır. Bu çerçevede katılımcılardan elde edilen bulgulara göre bazı görüşler şu şekildedir:

Ö2: “Buradaki halk daha çok Karadeniz'den gelen vatandaşlarımızın günlük olarak kullandığı dili öğrenmişler. Yanlış yerde kullanımları oluyor. Yalnız gerek konsolosluğun bünyesinde faaliyet gösteren Türk Okulu güzel Türkçemizin etkili ve düzgün konuşulmasında büyük katkı göstermektedir."

Ö4: "Herhangi bir sorun olduğunu düşünmüyorum."

Ö5: "Diğer ülkelerdeki faaliyetlerle kıyaslandiğında kurumsallaşmanın gerçekleşmediği, işlerin profesyonelce yapılmadığı göze çarpmaktadır.”

Ö6: "Belirgin bir eksiklik olduğunu düşünmüyorum. Dil konusunda yeterli olan öğrencilere takviye bir çalışma planlanırsa çok daha iyy olacağını düşünüyorum.”

Ö7: “Buraya özgü bir eksiklik yok. Türkiye şartları burada da geçerli.”

ö8: “Ortak sosyal, kültürel, sanatsal vb. etkinliklerin azlğı.”

3. 13. Gürcistan'da Türkçe ve Türk kültürünün daha verimli aktarımını sağlayabilmeye yönelik öğretmen görüşlerine ilişkin bulgular

Tablo 13: Türkçe derslerinin verimini arttırmaya yönelik önerilere ilişkin kod, frekans ve yüzdeler.

\begin{tabular}{llrl}
\hline Kod No & Kodlar & $\mathrm{f} \%$ \\
\hline 1 & Gürcü okullarılla güçlü bir etkileşim sağlanmalı & 1 & 12,5 \\
2 & Kreş açılmalı & 1 & 12,5 \\
3 & Profesyonel tanıtımlar yapılmalı & 1 & 12,5 \\
4 & Okula yabancı öğrencilerin alımı sağlanmalı & 1 & 12,5 \\
5 & Kültürel tanıtımlar yapılmalı & 4 & 50 \\
6 & Ortak sosyal, kültürel vb. etkinliklerin arttırılması & 1 & 12,5 \\
7 & Türk Kültür Merkezi adlı bir kurumun açılması & 1 & 12,5 \\
8 & Ödüllü yarışmalar düzenlenmeli & 1 & 12,5 \\
\hline
\end{tabular}


Gürcistan'da görev yapan öğretmenler Türkçe ve Tük kültürünün daha verimli aktarımı için birtakım önerilerde bulunmuşlardır. Buna yönelik görüşlerden bazıları ise şöyledir:

Ö2: “Özellikle Türk okuluna yabancı öğrencilerin de alnması sağlanmah, yalnzz bu öğrencileri okula kabulde özellikle ilköğretim düzeyinde yaş grubu ağırlkkta alnmal... Türkçeyi daha etkili öğrendikleri gibi kendi ana dillerinde arkadaş grubu içerisinde diğer öğrencilerle kullanacaklarından daha iyi etkileşim olacaktır."

Ö3: “Gezi."

Ö4: "Profesyonel tanttumlar yapulmall."

Ö5: "Gürcistan'da yabancı uyruklularla evli vatandaşlarımızın çocukları için kreşler açllmah, Türkçe bilmeyen ebeveynler için özel kurslar açlmah, burada yaşayan vatandaşlarımızın ülkemizle bağını diri tutmak için kültürel faaliyetler tertiplenmeli.”

Ö6: "Gürcü okulları ile etkileşimimin üst seviyelere çıkarılması gerektiğini, Türkçe konulu ödüllü yarışmalar düzenlenmesi gerektiğini düşünüyorum.”

Ö7: “Türk Kültür Merkezi formatında bir kurumun sürekli olarak kültürel faaliyetlerde bulunması faydah olabilir."

ö8: “Ortak sosyal, kültürel, sanatsal vb. etkinliklerin artırlması.”

\section{Sonuç ve öneriler}

Bu araştırmada Gürcistan'da Türkçenin yabancı dil olarak öğretimine katkı sunmak amacıyla MEB Batum Çok Programlı Anadolu Lisesinde (Batum Türk Okulu) öğrenim gören iki dilli öğrencilerin karşılaştıkları sorunlar ve bu sorunlara yönelik çözüm önerileri etrafında öğretmen görüşlerine başvurulmuştur. Bu çerçevede elde edilen bulgular ışığında çalışmanın sonuçları, önerileri ve alan yazınla değerlendirmesi şöyledir:

1. Öğretmenler iki dilli öğrencilerin Türkçe kullanımlarından, iletişim boyutlarına kadar birçok konuda görüşlerini belirtmişlerdir. Buna göre özellikle ilköğretim ve okulöncesi dönemde olmak üzere okula yeni başlayan iki dilli bazı öğrencilerin Türkçe bilmemelerinden kaynaklı sorunlarla karşılaşıldığı belirtilmiştir. Değinilen diğer maddelerin içeriği de bu durumla paralellik göstermektedir. Bunlar iki dilli öğrencilerin kendilerini ifade edememesi, öğrenme güçlükleri yaşaması gibi nedenlerle ilişkilendirilebilir. Özellikle katılımcılardan birinin "ebeveynlerden birinin hiç Türkçe bilmemesi” olarak ifade ettiği husus, Gürcistan'daki iki dilli öğrencilerde karşılaşılan sorunun temel nedeni olarak görülebilir. Bu çerçevede gerek iki dilli öğrenciler gerekse bu öğrencilerin ebeveynleri için çeşitli çalışmaların yapılması gerektiği anlaşılmaktadır. Bunun yanında farklı düzey ya da sınıflarda iki dilli öğrencilerin derse katılım sağlamaması kendilerini yetersiz hissetmelerinden kaynaklı olarak yorumlanabilir. Bunun da onların sınıf içi iletişimlerini olumsuz etkilediği ve psikolojik açıdan öğrenciler üzerinde kalıcı olumsuzluklar yaratabileceği düşünülebilir. Öğretmenler tarafından öğrencilerin kavramları anlayamama durumları ile mecaz, yan anlam gibi soyut dil becerilerinin algılanmasında yaşanan sorunlar da belirtilen diğer hususlardır. Öğretmenlerin yapmış oldukları bu tespitler çerçevesinde Gürcistan'da farklı düzeylerde iki dilli öğrenciler için çalışmaların yapılması gerektiği anlaşılmaktadır. Bu durum gerek öğrencilerin gerekse ebeveynlerinin dil gelişimi adına kaçınılmaz bir durumdur.

2. Öğretmenlerin iki dilli öğrencilerde karşılaştıkları olumluluğa yönelik tespitlerine bakıldığında farklı dilleri kolayca öğrenebilme, güçlü iletişim becerilerine sahip olma, karşılaştırma yapabilme, çok yönlü olabilme ve kültürler arası etkileşimi sağlayabilme olarak değerlendirildiği görülmektedir. Tüm bu tespitler çerçevesinde iki dilliliğin ileriki aşamalarda öğrenciler için oldukça yararlı bir bilgiye, kavrayışa 
olanak sağladığı söylenebilir. Ayrıca iki dilli öğrencilerin ilk aşamada hedef dilde zorlandıkları ve bunun da bir takım olumsuzlukları beraberinde getirdiği görülse de daha sonraki aşamalarda bunun onlar açısından oldukça faydalı bir bilgiye dönüştüğ̈̈ belirtilebilir. Bu nedenle araştırmacıların özellikle okula yeni başlayan iki dilli öğrencilere yönelik çalışmalar, etkinlikler veya ek dersler yapmaları gerekir. Öğretmenler tarafından iki dilliliğin belirtilen yararlarına bakıldığında bunun araştırmacılar tarafından dile getirilen hususlarla örtüştüğü görülür. Nitekim Andrade (2018: 1) iki dillilerle ilgili yapmış olduğu çalışmada iki dillliğin iletişim becerilerini geliştirdiği, bilişsel düşünmeye katkı sağladığı, okuma, yazma, problem çözme gibi beceri alanlarını geliştirdiğini belirterek bireylerin iki dilde düşünebilme becerilerinin onların eleştirel düşünmelerine daha fazla esneklik kazandırdığını belirtir. Bu çerçevede iki dil bilmek kültür, inanç gibi farklı özelliklere sahip olan bireyleri tanımayı, onlarla ilgili çeşitli okumalar yapmayı sağladığından bunun iki dilli bireylerin tek dilli bireylere oranla daha güçlü iletişim kurmalarına imkan tanıdığı görülür ve böylece onların gerek günlük yaşamlarına gerekse gelecekteki mesleki yaşamlarına katkı sağlayacağı düşünülebilir. Nitekim Kanada'da 2006'da istihdam oranlarını ortaya koyan bir çalışmanın göstergelerine bakıldığında hem Fransızca hem de İngilizce bilen iki dillilerin sadece İngilizce veya Fransızca konuşanlara göre daha iyi şartlara sahip oldukları tespit edilmiştir (Canadian Council on Learning, 2008: 2). Bu bağlamda bireylerin birden fazla dil bilmeleri onların farklı kültürlerdeki bireylerle iletişim kurup onları tanımalarına ve bakış açlarını çok boyutlu olmalarına imkan sağlar. Bu durumun da onların yaşamlarının her alanında bazı olumlu değişikliklerin oluşmasına katkı sunacağı söylenebilir. İnce'nin (2021) çalışmasında da görüleceği üzere bilişsel gelişimden iletişim becerilerine, dil edinim süreçlerinden farklı kültürleri tanımaya kadar iki dilliliğin bireye sağladığı avantajları oldukça fazladır.

3. Öğretmenler iki dilli öğrenciler için Türkçe ders sürelerinin yeterliliği konusunda farklı görüşler ortaya koymuşlardır. Onların çoğunluğu ders sürelerinin yeterli olduğunu ifade etmişlerse de okula yeni başlayan ve okul dışında Türkçe öğrenme pratikleri yapamayanlar için bunun yetersiz olduğunu ifade eden öğretmenler de söz konusudur. Bu bağlamda programdaki Türkçe ders saatlerinin yeterli olduğu söylenebilse de Türkçe becerileri yeterince gelişmemiş iki dilli öğrenciler için ek çalışmaların yapılması gerektiği de açıktır.

4. İki dilli öğrencilere ek derslerin yapılıp yapılmaması konusunda katılımcıların bir kısmı yapılması gerektiğini ifade etmişlerse de diğer bir kısmı da buna gerek olmadığını belirtmişlerdir. Bunun yanında ek derslere ihtiyaç olmadı̆̆ını belirten bazı öğretmenler iki dilli öğrencilerin dille ilgili problemlerinin bireysel olarak çalışmakla çözüleceğini ifade etmişlerdir. Bu çerçevede iki dilli öğrencilerin hedef dile dair sorunlarının ve buna yönelik yapılması gerekenlerin ortaya çıkarılması için katılımcıların düzeyleri, sınıfları, ebeveynlerinin Türkçeyi ne ölçüde bildikleri gibi birçok faktörün değerlendirilmesi ve buna göre yapılacakların kararlaştırılması gerekir.

5. Öğretmenler iki dilli öğrencilerde rastlanan olumsuz durumlara ilişkin çeşitli önerilerde bulunmuşlardır. Bunları öğrencinin, öğretmenin ve kurum ya da kuruluşların yapması gerekenler şeklinde farklı kategorilerde değerlendirmek mümkündür. Nitekim öğretmenler iki dilli öğrencilerin Türkçe öğrenme becerilerini geliştirebilmeleri için fazla okuma etkinliği çalışması yapmaları gerektiğini belirtmişler böylece öğrencilerin kendi gayretleri ile sorunu çözebileceklerini ifade etmişlerdir. Bunun yanında öğretmen veya kurumdan beklenen hususlar konusunda ise birçok çözüm önerileri saptanmıştır. Bunlar; okul öncesi dönemde dil çalışmaları yapılması gerektiği, kreş ve ebeveynlere yönelik kursların açılması, gezilerin düzenlenmesi, ek ders gibi takviye çalışmaların yapılması, öğrencilerin konuşma becerilerinin gelişimi adına uygun ortamların oluşturulması, düzeye göre dil becerilerinin tespit edilmesi şeklinde sıralanabilir. 
6. Yapılan çalışmanın ana çerçevesini oluşturmasa da iki dilli öğrencilerden bağımsız olarak iki dilli olmayan öğrencilerin de Türkçeyi kullanma becerilerinin belirlenmesi amacina yönelik bir tespit yapılması ihtiyacı duyulmuştur. Bu gereksinim ana dili konuşan öğrencilerin de yurt dışında eğitim görmelerinden ötürü duyulmuşstur. Ayrıca iki dilli öğrencilere yönelik yapılan tespitlerin iki dilli olmayan öğrencilerde de ne kadar görüldüğüne yönelik bir bilgiye duyulan ihtiyaçtan kaynaklanmıştır. Fakat öğretmenlerin tamamı iki dilli olmayan öğrencilerin Türkçeyi iyi bir şekilde bildiklerini veya kullandıklarını ifade etmişlerdir. Fakat kimi zaman yöresel kullanımlar ya da ağız özelliklerinin görüldüğü de belirtilmiştir. Bu çerçevede Gürcistan'da ana dili konuşan öğrencilerin Türkçe kullanımlarına yönelik bazı çalışmaların yapılması gerekebilir. Böylece öğrencilerin İstanbul Türkçesini yazma ve konuşma becerilerinde ne denli kullanabildikleri ve daha çok hangi ağızla Türkçenin kullanıldığı ve bunun sebeplerinin neler olduğu açıklık kazanmış olacaktır. Ayrıca öğretmenlerden birinin "Başlangıçtaki sorun maksimum 2 yıl içerisinde çözülmektedir." biçiminde bir ifadesinden özellikle okul öncesi ve birinci sınıftaki öğrencilerin genel olarak Türkçenin kullanımına dair sorunların en fazla iki yıl içinde çözüldüğü çıarımında bulunulabilir. Bu çerçevede iki dilli olmayan öğrenciler için de belirtilen sinfflarda ek ders ya da etkinlikler yapılabilir.

7. Çalışmada iki dilli öğrencilerin dil becerilerinde karşılaşılan sorun ya da olumsuzluklar konusunda ise öğretmenler farklı görüşler ortaya koymuşlardır. Buna göre aile ortamında Türkçenin etkin kullanılmaması, ebeveynlerin konuya dair ilgisizlikleri gibi düşünceler öne sürülmüştür. Bu çerçevede Gürcistan'da iki dilli öğrencilerin anne babalara yönelik bilgilendirici sunumlardan onların dil becerilerini geliştirebilecekleri etkinliklere kadar farklı çalışmaların yapılması gerekmektedir. Öğretmenler; öğrencilerin sözcük dağarcıklarının yetersizliği, kavramların algılanamayışı, olumsuzu aktarımlar (negatif transfer) gibi sorunların da görüldüğünü ifade etmişlerdir. Ayrıca belirtilen sorunlar çerçevesinde iki dilli öğrencilerde iletişimsizlik ve sosyal becerilerin zayıflığı gibi tespitlerin de öğretmenler tarafından yapıldığı ifade edilmiştir. İki dilli öğrencilerde görülen olumsuzluklara yönelik tüm bu tespitler konunun oldukça karmaşık bir yapı arz ettiğini de göstermektedir. Saptanan hususların çözümüne dair yapılacakların belirlenmesinde iki dilli öğrencilerin iki dillilik boyutlarının tespiti yapılmalı ve baskın dilin hedef dil üzerindeki etkisi, öğrenenin yaşı, dil edinme sırası veya bağlamı gibi pek çok hususta ayrıntılı bir değerlendirme yapılarak sorunun çözümüne odaklanılmalıdır. Örneğin öğretmenlerin belirtmiş oldukları olumsuz transfer konusu daha çok geç iki dilli bireylerde görülen bir durumdur. Bu iki dillilikte birey 6 - 7 yaşından sonra ikinci bir dil edinmeye başladığında olumlu ya da olumsuz aktarma gibi durumlarla karşılaşır. Nitekim geç iki dillilerde birinci dil ikinci dile oranla baskın olabilmektedir. Dolayısıyla zihinde iki dil arasındaki kontrolün tam olarak sağlanamaması öğrencinin daha tutuk kalmasına neden olabilmektedir (Süverdem ve Ertek, 2020; Pelham ve Abrams, 2014; Slobin, 1996; Hoffmann, 1991; Lal, etc., 2014). Bu bağlamda sorun olarak belirtilen bir durumun iki dilliğin boyutlarından biri olan geç iki dillilik üzerinden açıklanmasından hareketle iki dilliliğe yönelik bütün sorunların iki dilliliğin boyutları özelinde değerlendirilmesi gerekecektir. Bu çerçevede uygulamanın yapıldığı okulda iki dilli öğrencilere yönelik araştırmaların yapılıp bunların boyutlarının belirlenmesi gerekmektedir. Böylece sorunların çözümü de kolaylaşacaktır.

8. Öğretmenlere sorulan bir diğer soru ise iki dilli öğrencilerin bildikleri dilleri karışık olarak kullanıp kullanmadıklarına yöneliktir. Bu bağlamda öğretmenlerin yarısı böyle bir durumla karşılaşmadıklarını ifade etmişlerdir. Böyle bir sonucun ortaya çımasında öğretmenin branşından öğrencilerin düzey ve sınıfına kadar farklı etkenlerin olduğu söylenebilir. Dolayısıyla buna dair net bir sonucun alınabilmesi için de aynı merkezde iki dilli öğrencilere yönelik çalışmaların yapılması gerekmektedir. Böylece hangi sınıf ve düzeyde ne tür bir olumsuzluk görüldüğü daha sağlıklı değerlendirilebilir. Bunun yanında öğretmenlerin yarısı da iki dilli öğrencilerin bildikleri dilleri karıştırdıklarını ifade etmişlerdir. Buna 
gerekçe olarak da konuşulan dillere hâkim olamama, olumsuz aktarım yapma, iyi bildikleri dille eksiklikleri tamamlama biçiminde görüşler öne sürülmüştür. Son olarak "nadiren” ifadesini kullanan öğretmenler de söz konusudur. Bu durumun tespit edilmesinde sınıf, yaş, ebeveynlerin Türkçe düzeyi gibi birçok faktörün etkisi olduğu söylenebilir. Öğretmenler tarafından tespit edilen olumsuzluklara bakıldığında öğrencilerin öğrendiği ikinci dile tam anlamıla hâkim olamaması ve aktarmalar yapabilmesi, iki dillilikte kod değiştirme olarak tanımlanan bir engeldir. Andrade (2018: 1) kod değiştirmeyi bir cümle veya kelime içinde bir dilden diğerine geçebilme yeteneği olarak açıklar ve bunun nedeni olarak da ana dil ile ikinci dil arasında bireyin zihninin bir karışıklık yaşaması olarak ifade eder. Dolayısıyla öğrencilerin iki dil arasındaki geçişleri düzenli yapamaması bazı karışıklıklara neden olduğu ve bu durumun çeşitli beceri alanlarında birtakım olumsuzlukları görünür kıldığı söylenebilir.

9. İki dilli öğrencilerin hangi dil becerilerine yönelik çalışmalar yapılması gerektiği sorusuna yönelik olarak öğretmenlerin çoğunluğu tüm beceri alanlarında çalışmalar yapılması gerektiğini ifade etmişlerdir. Fakat özellikle konuşma becerisi üzerinde öğretmenlerin durdukları görülmüştür. Bu husus Thornbury'nin (2005) "ana dili konuşurları, yabancı dil konuşurları ile ilgili olarak, yanlış vurgu ve tonlamanın, anlaşılmanın önündeki en büyük engel olduğu” düşüncesini de desteklemektedir (akt. Keser, 2018: 18). Kara da (2010: 684) birçok yabancının ana dillerinde olmayan sesleri çlkarmakta zorlandıklarını veya kimi sesleri birbirleriyle karıştırdıklarını belirtir. Dolayısıyla konuşma becerisine ilişkin sözcüklerin sesletimi başta olmak üzere birçok alanda, öğrencilerin kendilerini ifade ederken öğretmenlerin de onları anlamaya çalışırken zorlandıkları söylenebilir. Bu bağlamda konuşma becerisi üzerinde daha çok durularak iki dilli öğrencilere yönelik Türkçe öğretimine dair etkinlikler yapılabilir.

10. Öğretmenler iki dilli öğrencilerin en çok zorlandıkları beceri alanları ve bunun nedenleri konusunda ise farklı görüşler ortaya koymuşlardır. Özellikle konuşma becerisi konusunda "ü, ş, ç” seslerinin telaffuzu konusunda öğrencilerin zorlandıkları belirtilmiştir. Bu konuda öğrencilerin ana dillerinin ve düzeylerinin tespitiyle konunun daha iyi anlaşllabileceği düşünülmektedir. Örneğin Gürcü alfabesinde “ü, ö, ı" ünlüleri bulunmamaktadır. Fakat buna rağmen telaffuzda "ı" sesinin kullanıldığı görülse de "ü ve "ö" sesleri için aynı şey söz konusu değildir. Bu çerçevede öğretmenler tarafından telaffuza yönelik belirtilen olumsuzlukların nedenleri üzerinde doğru bir tespit yapabilmek için öğrencilerin ana dillerinin ne olduğu, hedef dilde hangi düzeyde bulundukları ve ne tür bir telaffuz sorunu yaşadıklarının tespit edilip ona göre yapılacak çalışmaların düzenlenmesine gidilmelidir. Nitekim bu çalışmadan elde edilen verilerden hemen sonra öğrencilere ve ebeveynlere yönelik çalışmalara da başlanmıştır. Okuma becerisi konusunda ise okuduğunu anlayamama, sözcük dağarcıklarının yetersizliği biçiminde tespitler yapıldı ̆̆ı gibi dinleme ve yazma becerilerinde de öğrencilerin zorlandıkları ifade edilmiştir. Dolayısıyla tüm beceri alanlarına ilişkin ayrıntılı çalışmaların yapılması gerekmektedir.

11. Öğretmenler iki dilli öğrencilerin en çok başarılı oldukları dil becerilerinin iletişim, konuşma ve okuma olduğunu ifade etmişlerdir. Bu tespit için denilebilir ki iki dilli öğrenciler hedef dili iyi öğrendikten sonra diğer öğrencilere göre bazı alanlarda daha başarılı olabilmektedir. Bunun da onların iletişim becerileriyle doğrudan gözlemlenebildiği öngörülmektedir. Skibba (2018) tarafından tek dillilerle iki dilliler arasında farklılığı ortaya koyma adına yapılan bilişsel bir çalışmada tek dillilere oranla iki dillilerde, prefrontal ve parietal kortkekste daha fazla hücre gövdesi olduğu bilimsel olarak tespit edilmiştir. Ayrıca iki dillilerde nöronlar arasındaki bağlantıya etki eden bir maddenin olduğu bunun da iletilerin sinir ağları arasında beyde hızlı ve verimli bir şekilde iletilmesini sağladığını saptar. $\mathrm{Bu}$ çerçevede iki dilli bireylerde bilişsel olarak gelişen bir durumun onların günlük hayatta başkalarıyla kurdukları iletişime de katkı sağladığı söylenebilir. 
12. Çalışmada iki dilli öğrencilerden bağımsız olarak Gürcistan'da Türkçe eğitimi ve öğretimi alanında görülen sorun ya da eksikliklere yönelik öğretmenlerin görüşlerine de başvurulmuştur. Bu çerçevede öğretmenlerin çoğunluğu herhangi bir sorunun olmadığını belirtmişlerdir. Fakat bazı öğretmenler ortak sosyal, kültürel ve sanatsal etkinliklerle dil konusunda ek çalışmaların yapılması gerektiğini ifade etmişlerdir. Ayrıca bir diğer olumsuzluğun da kurumsallaşmanın henüz gerçekleşmediği biçiminde öne sürüldüğü tespit edilmiştir. 2016 yılında ve yurt dışında kurulan bir okulla ilgili bazı eksikliklerin yaşanabileceğini doğal karşılansa da eleştirilerin tespitiyle yaşanan aksaklıkların da çözümü kolaylaşacaktır. Bu nedenle okula yönelik olarak aksaklık/eksikliklerin belirlenmesi için de öğretmen, öğrenci ve velilerden görüş alınması faydalı olacaktır. Yıldız’ın (2012) Almanya'da yaşayan Türklerle ilgili veli, öğrenci ve öğretmenlere yönelik yapmış olduğu çalışmada görüleceği üzere Türkçe öğretimine yönelik bakış açılarının farklılı̆̆ sorunların tespiti ve ortaya konulacak önerilerde de çeşitlilik oluşturabilmektedir.

13. Yapılan araştırmada bir önceki soruyla ilişkili olarak Gürcistan'da Türk vatandaşlarına yönelik olarak Türkçe ve Türk kültürünün daha verimli aktarımını geliştirebilmek için ne tür önerilerin olabileceği de öğretmenlere sorulmuştur. Buna gore çoğunlukla kültürel çalışmalar yapılması gerektiği ifade edilmiştir. Gürcü okullarıyla etkileşimlerin sağlanması, kreş açılması, profesyonel tanıtımlar yapılması, okula yabancı öğrencilerin alınması, ödüllü yarışmalar düzenlenmesi, ortak sosyal, kültürel ve sanatsal etkinliklerin arttırılması ve Türk Kültür Merkezi gibi bir kurumun sürekli kültürel etkinlikler düzenlemesi şeklinde görüşler öne sürülmüştür.

\section{Kaynakça}

Abukan, M. (2021). Ana dili Türkçe olan öğreticilerin görüşlerine göre Gürcistan'da Türkçenin yabancı dil olarak öğretimi. SSD Journal International Conference on Social Sciences and Humanities. ss. 73-85. Ankara.

Aksan, D. (1998). Her Yönüyle Dil - Ana Çizgileriyle Dilbilim. Ankara: TDK Yayınları.

Altıparmak Yılmaz, H. M. (2020). Avustralya'da yaşayan Türklerin dil görünümlerinin iki dillilik bağlamında incelenmesi. [Yayımlanmamış doktora tezi]. Gazi Üniversitesi.

Andrade, A. (2018). Bilingualism in the education of adolescents. https://www.csustan.edu/sites/default/files/groups/University\%20Honors\%20Program/Journ als_two/28_andrade.pdf. [Erişim Tarihi: 20.07.2021].

APA Psikoloji Sözlüğ̈̈ (2021). Multilingualism. American Psychological Association. https://dictionary.apa.org/multilingualism. [Erişim Tarihi: 25.10.2021].

Avrupa Birliği Konseyi (2005). A new framework strategy for multilingualism. COM (2005) 596, Brussels.

Bican, G. (2014). I. Uluslararası Avrupa'da iki dilli Türklerin ana dili eğitimi çalıştayı. Zeitschrift für die Welt der Türken/Journal of World of Turks, 6(1), 317-320.

Bloomfield, L. (1935). Language. London: Allen \& Unwin Ltd Publishers, pp.55-56.

Canadian Council on Learning. (2008). Parlez-vous français? The advantages of bilingualism in Canada. http://en.copian.ca/library/research/ccl/bilingualism/bilingualism.pdf. [Erişim Tarihi: 21. 07. 2021].

Çakır, M. (2016). Çok kültürlü ortamlardaki çocuklara Türkçe öğretimi ve bireysel iki dillilik. III. Avrupalı Türkler Anadili Eğitimi Çalıştayı Bildirileri, 67-103. https://www.academia.edu/. [Erişim Tarihi: 25.10.2021].

Güncel Türkçe Sözlük. (2021). TDK Yay., Ankara. https://sozluk.gov.tr/. [Erişim Tarihi: 15.06.2021].

Güzel, A. (2010). İki Dilli Türk Çocuklarına Türkçe Öğretimi. Ankara: Öncü Kitap. 
Hamers, J. F., \& Blanc, M. H. (2000). Bilinguality and Bilingualism. (2nd ed.). Cambridge University Press.

Hoffmann, C. (1991). An Introduction to Bilingualism, New York: Longman.

İmer, K., Kocaman, A., \& Özsoy, A. S. (2011). Dilbilim Sözlüğü. İstanbul: Boğaziçi Üniversitesi.

İnce, B. (2021). İkidilliliğin avantajları ve dezavantajları. İ. Güleç, B. İnce, H. N. Demiriz (Ed.), İkidillilik ve ikidilli çocukların eğitimi içinde (1.baskı), ss. 429-442. İstanbul: Kesit Yayınları.

Jasone, C. and Genesee, F. (1998). Beyond Bilingualism: Multilingualism and Multilingual Education. (eds.), Clevedon, England: Multilingual Matters.

Kara, M. (2010). Gazi Üniversitesi TÖMER öğrencilerinin Türkçe öğrenirken karşılaştıkları sorunlar ve bunların çözümüne yönelik öneriler. Türk Eğitim Bilimleri Dergisi, 8(3), 661- 696.

Keser, S. (2018). Yabancı dil olarak Türkçe öğretiminde konuşma becerisini geliştirmede karşılaşılan güçlükler. [Yayınlanmamış yüksek lisans tezi]. Hacettepe Üniversitesi.

Lal, T. V.; Rodrıguez, G. G.; Narasımhan, B. (2014). Thinking for speaking in early and late bilinguals. Bilingualism: Language and Cognition, 17(1), 139-152.

Vardar, B. (2002). Açıklamalı Dilbilim Terimleri Sözlüğü. İstanbul: Multilingual.

Pelham, S. D., \& Abrams, L. (2014). Cognitive advantages and disadvantages in early and late bilinguals. Journal of Experimental Psychology: Learning, Memory, and Cognition, 4O(2), 313-325.

Skibba, R. (2018). How a second language can boost the brain. https://knowablemagazine.org/article/mind/2018/how-second-language-can-boost-brain. [Erişim Tarihi: 27.07.2021].

Slobin, D. I. (1996). "From 'thought and language' to 'thinking for speaking,"' in Rethinking Linguistic Relativity, eds J. J. Gumperz and S. C. Levinson (Cambridge, UK: Cambridge University Press), 70-96.

Süverdem, F. B. ve Ertek, B. (2020). İki dillilik ve iki kültürlülük: göç, kimlik ve aidiyet. The Journal of International Lingual Social and Educational Sciences, 6(2), 183-207. https://research.pomona.edu/lise-abrams/files/2018/o8/pelham_abrams_14.pdf. [Erişim Tarihi: 23.10.2021].

Thornbury, S. (2005). How to Teach Speaking. Pearson.

Tucker, G. R. (1999). A Global perspective on bilingualism and bilingual education. Carnegie Mellon University. https://cal.org./. [Erişim Tarihi: 23.10.2021].

Wang, H. L. (2021). Definitions of Bilingualism and their Applications to the Japanese Society. https://core.ac.uk/download/pdf/230948509.pdf. [Erişim Tarihi: 15.06.2021].

Yıldırım, A. ve Şimşek, H. (2011). Sosyal Bilimlerde Nitel Araştırma Yöntemleri. Ankara: Seçkin Yayınları.

Yıldız, C. (2012) Yurt Dışında Yaşayan Türk Çocuklarına Türkçe Öğretimi (Almanya Örneği). Ankara: Yurtdışı Türkler ve Akraba Topluluklar Başkanlığı. 